Uludag Univ. J. Fac. Vet. Med.

32 (2013), 1: 67-70

\title{
Holstein-Friesian Irkı Bir Sığırda Gözlenen Pulmoner Tüberküloz ve Hepatik Telengiektazi Olgusu
}

\author{
Volkan IPEK \\ Ahmet AKKOÇ \\ M. Müfit KAHRAMAN
}

Geliş Tarihi: 30.10 .2013

Kabul Tarihi: 30.10 .2013

\begin{abstract}
Özet: Sığırlarda karaciğer telengiektazisi etiyolojisi ve patogenezisi henüz net olarak ortaya konulamamıştır ve mikroskobik görünümüyle hepatosit kaybı şekillenen bölgelerde içleri eritrositler ile dolu sinuzoid genişlemeleri olarak tanımlanır. Lezyonun makroskobik görünümü nedeniyle karaciğerin insan tüketimine sunulamaması ve organın șiddetli olarak etkilendiği olgularda da et ve süt veriminde düşüşe yol açması nedeniyle ekonomik önemi olan bir durumdur. Peliozis hepatis insan ve hayvanlarda gözlenen ve karaciğerde içi kan dolu kistik boşluklarla karakterize bir durumdur. İnsanlarda gözlenen peliozis hepatis akciğer tüberkülozu ile ilişkilendirilmiştir. Sığırların karaciğer telengiektazisi ile insanlarda gözlenen peliozis hepatis arasında da patojenez benzerliği mevcuttur. Sunulan bu vakada 3 yaşlı, Holstein-Friesian ırkı bir inekte gözlenen akciğer tüberkülozu ve karaciğer telengiektazisi mikroskobik olarak değerlendirilmiş, insanlardaki peliozis hepatis-akciğer tüberkülozu arasındaki ilişkiye benzerliğe dikkat çekilmesi amaçlanmıştır.
\end{abstract}

Anahtar Kelimeler: Sığır, karaciğer, telengiektazi, akciğer, tüberküloz.

\section{Case of Lung Tuberculosis and Liver Telangiectasis in a Holstein-Friesian Cattle}

Abstract: Liver telangiectasis with an obscure etiology and pathogenesis, is characterized by hepatocyte loss and sinusoidal enlargements with blood. The condition causes condemnation of livers and in severe cases decreases in meat and milk yield, therefore causes economic losses. Peliosis hepatis is a condition of humans and animals characterized by blood filled cystic spaces, and has been associated with lung tuberculosis in humans. Peliosis hepatis of humans and liver telangiectases of cattle are pathogenically similar conditions. This report investigates a case of lung tuberculosis and liver telangiectasis in a 3 years old, Holstein-Friesian cow and emphasizes its similarity to the relationship between peliosis hepatis-lung tuberculosis in humans.

Key Words: Bovine, liver, telangiectasis, lung, tuberculosis.

\section{Giriş}

Telengiektazi karaciğerde hepatosit kaybının olduğu alanlarda başlangıçta oluşan erken sinüzoidal dilatasyon (pre-telengiektazi) ve takiben şekillenen, belirgin kan dolu boşluklar olarak tanımlanır ${ }^{3,5,8}$. Makroskobik olarak 1-2 mm büyüklüğünden birkaç santimetreye kadar değişen boyutta, koyu mavi-mor renkli alanlar şeklinde görülür; bu yapıların mikroskobik incelemesinde hepatosit kayb1 ve sinuzoid genișlemeleri dikkati çeker ${ }^{3}$. Çoğunlukla ineklerde rastlanmakla birlikte kedilerde de gözlenebilen bir durumdur ${ }^{1,3,9}$. Lezyon gözlenen karaciğer bölümlerinin et endüstrisinde kullanılamaması, ayrıca geniş karaciğer alanlarının etkilendiği vakalarda karaciğer fonksiyon bozukluğuna bağlı et ve süt veriminde düşmeye sebep olması nedeniyle ekonomik kayıp söz konusudur ${ }^{1,8}$.

$\mathrm{Bu}$ vaka sunumunda bir inekte gözlenen akciğer tüberkülozu ve hepatik telengiektazi arasındaki olası ilişkinin mikroskobik bulgular 1şı̆̆ında yorumlanması amaçlanmıştır.

\footnotetext{
Uludağ Üniversitesi Veteriner Fakültesi Patoloji Anabilim Dalı, volkanipek@uludag.edu.tr
} 


\section{Materyal-Metot}

Mezbahada kesilen 3 yaşl1, HolsteinFriesian 1rkı bir ineğin iç organlarının makroskobik incelenmesinde karaciğer ve akciğerlerinde lezyonlar gözlenmiş, mikroskobik inceleme amacıyla organ örnekleri alınmıştır. Örnekler $\% 10$ 'luk formaldehit tespitini takiben rutin işlemlerden geçirilerek parafin bloklara gömülmüş, 5 mikrometre kalınlığında kesitler alınarak hematoksilen-eozin ile boyanmıștır.

\section{Bulgular}

Makroskobik incelemede, karaciğerde subserozal ve parenkimal yerleşimli, çok sayıda, çapları $1 \mathrm{~cm}$ 'ye ulaşan koyu kırmızı-mor renkli alanlara rastlandı (Resim-1). Gögüs boşluğunun muayenesinde sağ ve sol kaudal akciğer loblarında yerleşim gösteren, kesit yüzleri sarı renkte ve peynirimsi görünümde bir içerikle dolu, multifokal nekrotik alanlara görüldü (Resim-2). Mediastinal lenf yumruları şiddetli büyümüştü. Böbreklerin bazı loblarında açık renkli sahalar şekillenmişti.

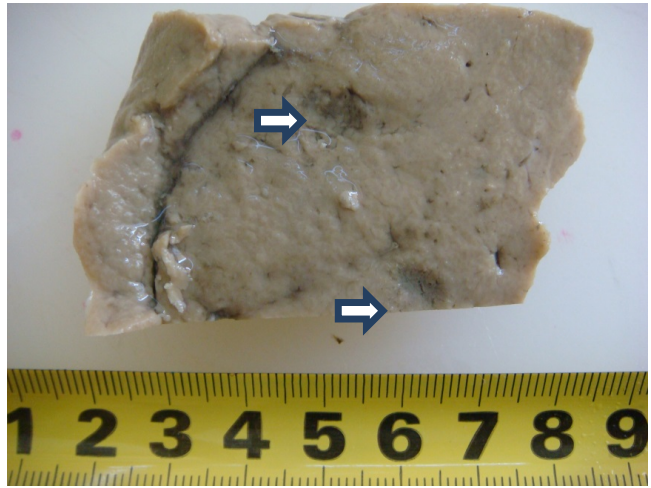

Resim-1. Formaldehit tespiti sonrası karaciğerde gözlenen telengiektazi alanlarl (oklar)

Figure-1. Telangiectatic areas in liver after formaldehyte fixation (arrows)

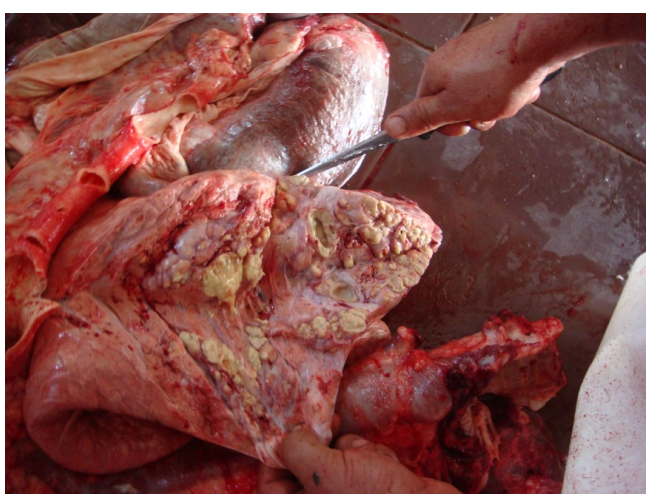

Resim-2. Akciğerde multifokal nekrozlar Figure-2. Multifocal necroses in lung
Mikroskobik incelemede, karaciğerde bazı mikroskop sahalarında sinuzoidlerin genişlediği, içlerinin eritrositlerle dolu olduğu ve komşu alanlarda bağ doku ve kollajen artışı dikkati çekti (Resim-3 ve 4). Portal alanlarda lenfosit infiltrasyonlarına rastlandı (Resim-5). Akciğerlerde yaygın şekilde, merkezinde kazeifikasyon nekrozunun şekillendiği ve yer yer kireçlenme alanları içeren, çevresinde yoğun lenfosit, plazma hücresi, histiyosit, dev hücresi kümeleri ile bağ doku artışının gözlendiği odaklar şekillenmişti. Lezyonların çevresinde gözlenen dev hücreleri tipik Langhans tipi dev hücresi morfolojisine sahipti. (Resim-6). Mediastinal lenf yumrusunda da akciğerde gözlenen bulgulara benzer çok sayıda granulomatöz alanlar bulunuyordu (Resim-7). Böbreklerin incelenmesinde hafif şiddette, multifokal intersitisyel nefritis tablosu gözlendi.

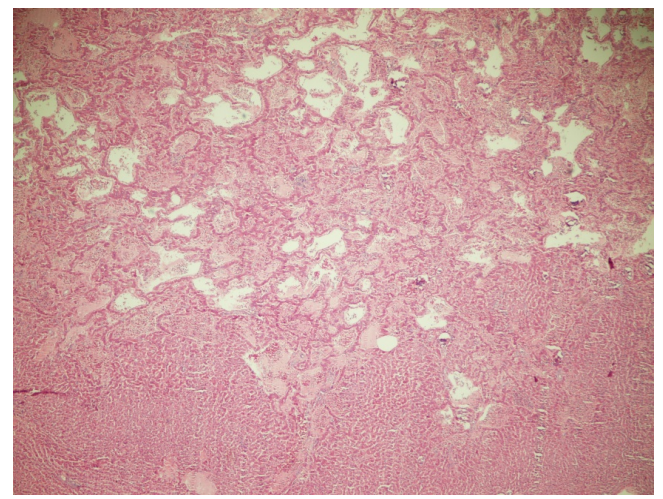

Resim-3. Karaciğerde içleri eritrositler ile dolu genişlemişs sinuzoidlerin mikroskobik görünümü. $H \& E, 40 x$.

Figure-3. Microscopic appearance of eritrocyte filled dilated sinusoids in the liver. $H \& E, x 40$.

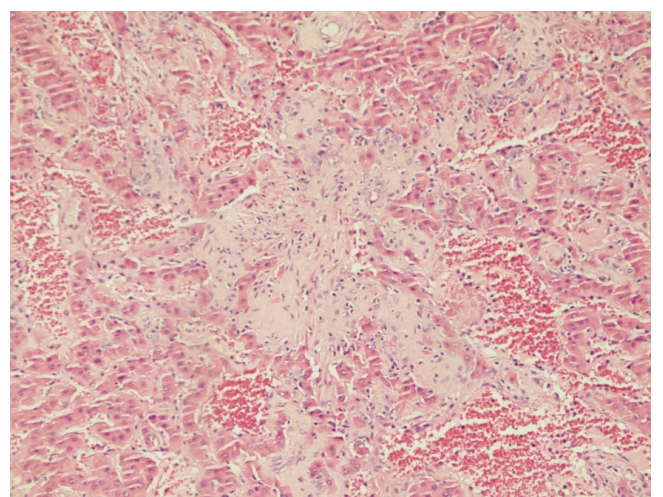

Resim-4. Karaciğerde telengiektazik sinüzoidler ve interstisyel băg doku ve kollajen artışının mikroskobik görünümü. $H \& E, 100 x$

Figure-4. Microscopic appearance of telangiectasic sinusoids and interstitial connective tissue proliferation and collagen increase in the liver. $H \& E, x 100$. 


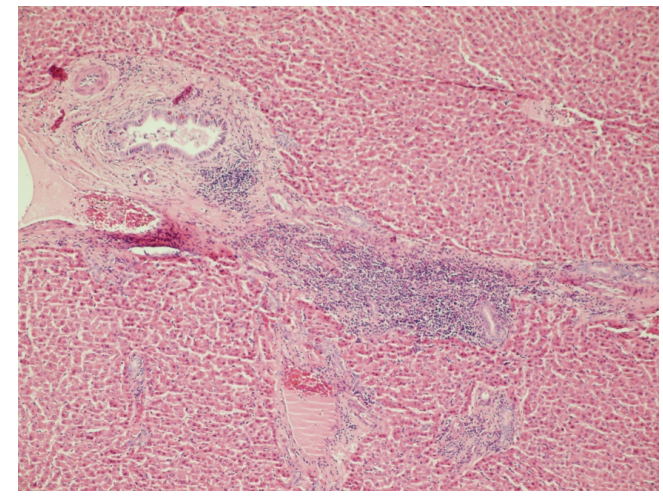

Resim-5. Karaciğerde portal bölgede gözlenen şiddetli mononükleer hücre infiltrasyonlart. $H \& E$, $40 x$.

Figure-5. Severe mononuclear inflammatory cell infiltrates in portal region in liver. $H \& E, x 40$.

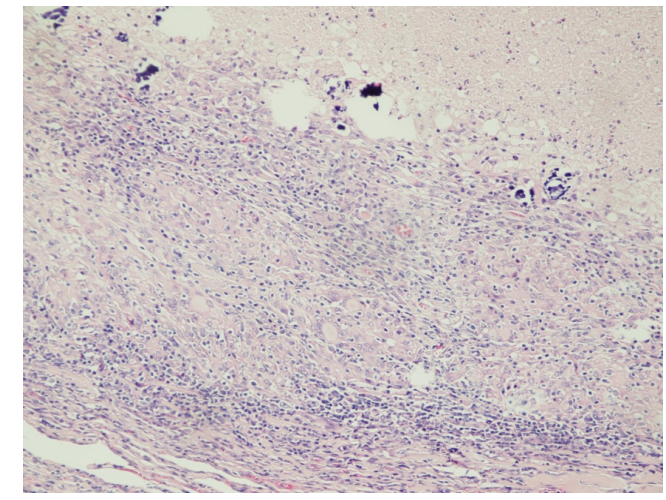

Resim-6. Akciğerde merkezi nekrotik, çevresinde lenfosit, histiyosit, Langhans tipi dev hücreleri (ok) ve bağ doku artışı gözlenen tüberkülün mikroskobik görünümü. $H \& E, 100 x$.

Figure-6. Microscopical appearance of a tubercule that centrally is necrotic and surrounded by lymphocytes, histiocytes, Langhans giant cells (arrow) and connective tissue in lung. $H \& E, x 100$.

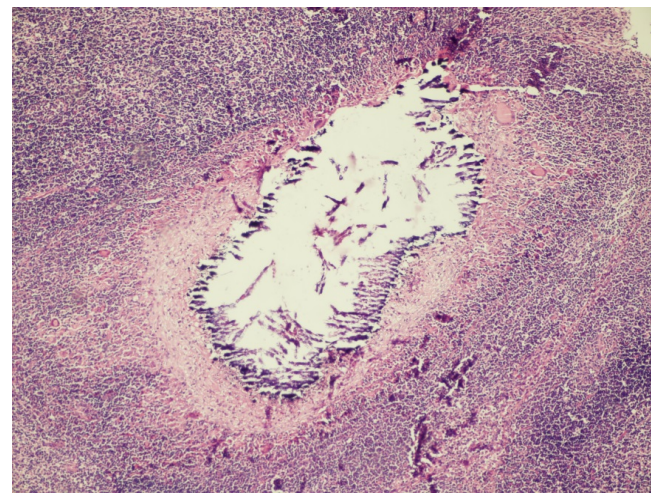

Resim-7. Mediastinal lenf yumrusunda gözlenen merkezi nekrotik ve kalsifiye alanlar içeren, çevresi bă̆ doku ile sınırlandırılmış tüberkülün mikroskobik görünümü ve Langhans tipi dev hücresi (ok). $H \& E$, 100x.

Figure-7. Microscopical appearance of a tubercule that is centrally necrotic and surrounded by connective tissue in the mediastinal lymph node and a Langhans giant cell (arrow). $H \& E, x 100$.

\section{Tartışma}

Telengiektazinin sebebi tam olarak bilinmemekle beraber, portal sistem yangılarının, fokal hepatik nekrozun ve toksik bitkilerin etiyolojide rol oynayabileceği ile ilgili görüşler bulunmaktadır ${ }^{8}$. Lezyonun patogenezi ile ilgili olarak temelde hepatosit kaybının oluştuğu bölgelerde telengiektazinin şekillendiği düşünülmektedir $^{3}$. Marcato ve arkadaşlarına ${ }^{5}$ göre telengiektazinin temelinde yatan primer sebep, olası metabolik ve toksik ajanlara bağlı olarak sinüzoidal bariyerde meydana gelen değişikliklerdir. $\mathrm{Bu}$ değişiklikler sonucunda perisinüzoidal bariyerde bazal membran komponentlerinde artış ve fibrozis gözlenmektedir. Buna bağl1 olarak hepatositler ile kan arasindaki besin ve oksijen alışverişinde aksama sonucunda hepatosit atrofisi ve nihayet sinüzoidal bozulma oluşmaktadır. Burada sunumu yapılan vakada, karaciğerde portal alanlarda gözlenen mononükleer hücre infiltrasyonları ve telengiektazi bölgelerinde dikkati çeken bağ doku artışı da bahsedilen yangısal patogenez ile uyumlu değişikliklerdir.

İnsanlarda gözlenen ve yine karaciğerde kan dolu kistik genişlemelerle karakterize olan peliozis hepatis'in pulmoner tüberküloz hastal1$\breve{g}_{1}$ ile ilişkisinin olduğu bildirilmiştir ${ }^{2,4,6,9}$. Stotland ve arkadaşlarının ${ }^{10}$ yaptığı bir çalışmada 
normal ve telengiektatik karaciğerlerde bakteriyel kompozisyon araştırılmış ve telengiektazi ile bakteriyel hastalıklar arasında herhangi bir ilişki kurulamamıştır. Sığırlarda gözlenen karaciğer telengiektazisi ve insanlarda gözlenen peliozis hepatis, temelde olası metabolik veya toksik ajanlara bağlı hasarı takiben bazal membran komponentlerinin perisinüzoidal alanda anormal birikimleri; bu bölgede şekillenen fibrozise bağlı olarak artan kan basıncı ve hipoksiye bağlı hepatosit atrofisi sonucunda şekillenmektedir. $\mathrm{Bu}$ yönleriyle insan peliozis hepatis hastalığı ile sığır karaciğer telengiektazisi benzer patogeneze sahiptirler ${ }^{5}$. Mekanizmasi tam olarak bilinmemekle birlikte, patogenezdeki bu benzerlik nedeniyle, bizim gözlemlediğimiz akciğerdeki şiddetli tüberküloz lezyonları ile karaciğerdeki telengiektazi arasında, insanlardaki peliozis hepatis-akciğer tüberkülozu arasındakine benzer bir ilişki bulunması olasıdır. Nitekim karaciğerde portal bölgelerde gözlenen yangısal hücre infiltrasyonları da bu görüşü desteklemektedir.

Sığırlarda karaciğer telengiektazisi dünya genelinde gözlenmektedir ${ }^{1,5,7,8}$. Türkiye'de yap1lan bir çalışmada Atasever ve arkadaşlar1 ${ }^{1}$ mezbahada kesilen sığırlarda karaciğer telengiektazisi insidensini \%2,3 olarak belirlemişlerdir. Amerika'da sığırların karaciğerinde telengiektazi gözlenme oranının \%10'un üzerinde olduğu ve 1997 verilerine göre yaklaşık 23 ton ürünün bu nedenle kullanılamadığı belirtilmiştir ${ }^{10}$.

Yazarların bilgisine göre sığırlarda karaciğer telengiektazisinin patogenezinde tüberküloz hastalığının rol oynayabileceği ile ilgili daha önce bildirilen herhangi bir rapora rastlanmamıştır. İnsanlarda peliozis hepatis-akciğer tüberkülozu arasındaki ilişkiye dair bulguların vakamıza benzerliği böyle bir ilişkinin sığırlarda da olabileceğini düşündürmektedir.

\section{Kaynaklar}

1. Atasever A., Vural S.A., Berkin S., 2002. Incidence and pathologic studies on liver telangiectasis in beef cattle. Turk J Vet Anim Sci, 26, 235238.

2. Bae E.H., Choi S.J.N., Lee J.H., Kim S.W., 2010. Peliosis hepatis cured with anti-tuberculosis medication in a hemodialysis patient. Korean $\mathrm{J}$ Nephrol, 29: 167-170

3. Cullen J.M., and Brown D.L., 2012. Hepatobiliary System and Exocrine Pancreas. In Zachary J.F., and McGavin M.D. (Eds.), Pathologic Basis of Veterinary Disease, Fifth Edition. Elsevier Mosby, Missouri, USA, pp. 427.

4. Jones, T.C, Hunt, R.D., 1983. Hepatic Abscesses and Related Conditions. In Veterinary Pathology. Lea and Febiger, Philadelphia, USA, pp. 14231426.

5. Marcato P. S., Bettini G., Della Salda L. and Galeotti M., 1998. Pretelangiectasis and telangiectasis of the bovine liver: A morphological, immunohistochemical and ultrastructural study. $J$ Comp Pathol, 119, 95-110.

6. Meyniel D, de Plunkett T, Huguier M, Mayaud C, Pieron R., 1982. Hepatic peliosis with portal hypertension in pulmonary tuberculosis. Nouv Presse Med, 11: 3066.

7. Robinson T.J., Jasper D.E., Guilber H.R., 1951. The isolation of Spherophorus necrophorus from the rumen together with some feed lot data on abscess and telangiectasis. J Anim Sci, 10, 733741.

8. Soto J.A. and Delgado F., 1993. Ultrastructure of bovine liver telangiectasis. Rev Cient, 3, 46-49.

9. Stalker M.J. and Hayes M.A. 2007. Liver and Biliary System. In Maxie M.G. (Ed.), Jubb, Kennedy and Palmer's Pathology of Domestic Animals: Volume 2, Fifth Edition, Elsevier Saunders, USA, pp. 335.

10. Stotland E.I., Edwards J.F., Roussel A.J., Simpson R.B., 2001. Bacterial microflora of normal and telangiectatic livers in cattle. $J$ Am Vet Med Assoc, 219, 36-39. 